\title{
VENE AKTSENT EESTI KEELES: AKUSTILISE ANALÜÜSI TULEMUSI
}

\section{Lya Meister}

Ülevaade. Aktsent on mõõdetav ja objektiivselt kirjeldatav kvantitatiivsete näitajate abil. Analüüsitavaks materjaliks on eestikeelse kõne salvestused, millest on mõõdetud mitmete akustiliste tunnuste väärtusi: intensiivsust, põhitooni, häälikute, silpide ja sõnade kestusi, vokaalide formantsagedusi. Aktsendiga ja normikohase hääldusega kõnest mõõdetud akustiliste tunnuste väärtuste võrdlemisel on leitud erinevate aktsendinähtuste kvantitatiivsed näitajad, mille tõlgendamine eesti ja vene keele fonoloogilises süsteemis võimaldab selgitada aktsendinähtuste olemust. Uurimuse põhjal võib järeldada, et vene aktsent avaldub eesti keeles erinevate akustiliste tunnuste kombinatsioonina, millest olulisemad on temporaalse struktuuri ja rõhuparameetrite ning häälikute kvaliteediga seotud tunnused.

Võtmesõnad: aktsent, foneetika, vokaalid, häälikute ja silpide kestused, kestussuhted, sõnarõhk, akustiline analüüs, eesti keel, vene keel

\section{Sissejuhatus}

Iga inimene on teoreetiliselt võimeline lisaks emakeelele omandama mis tahes võõrkeele(d). Teise keele õppimine ei alga "vaakumist" - tavaliselt on õppija selleks ajaks peaaegu täielikult omandanud emakeele baasstruktuurid, samuti on tal olemas kõik anatoomilised ning kognitiivsed eeldused uue keele omandamiseks. Iga võõrkeele õppimine lähtub emakeele grammatilistest struktuuridest ja hääldusmallidest - neist on tingitud ka suurem osa võoorkeele omandamisel esinevatest grammatilistest ning hääldusvigadest. Juba Nikolai Trubetzkoy (1939) märkis, et emakeele foneetilised kategooriad moodustavad "sõela", mille hiljem peavad läbima omandatava keele foneetilised üksused.

Eesti riik tegeleb juba aastaid muukeelse elanikkonna integreerimisega ühiskonda. Selle protsessi eelduseks on heal tasemel keeleõpe, mis ei tohiks piirduda 
sõnavara ja grammatika õpetamisega, vaid peaks tähelepanu pöörama ka keelte (vene ja eesti keele) fonoloogiliste süsteemide võrdlusele. Teist keelt rääkides lähtub kõneleja oma emakeele hääldusmallidest, kandes need üle võõrkeele vastavatele häälikutele. Kuna aga eri keelte ühtesid ja samu häälikuid hääldatakse sageli erinevalt, siis on korrektne hääldamine raskendatud. Kõnelemisel kaasneb võõrapärane hääldus - aktsent. Aktsendivaba häälduse saavutamise esmaseks eelduseks on vabanemine fonoloogilisest kurtusest, mida on võimalik saavutada kontrastiivse taju- ja hääldustreeningu abil (Kjellin 1999). Praeguses keeleõppes kahjuks puudub vastav metoodika ja tehniline baas heal tasemel treeningõppe läbiviimiseks.

Aktsendivaba kõne tähendab keele täielikku omandamist, milleni kõik ei jõuagi. Ja ega aktsent ei kujutagi endast suurt probleemi, kui see ei takista kõnest arusaamist, kuid kõneleja peaks siiski püüdlema häälduse loomulikuma kõla poole. Enesestmõistetav ja kohustuslik peaks aga olema aktsendivaba hääldus keeleõpetajale.

Eesti keele kui teise keele häälduse eripärast ja hääldusvigadest kirjutab Einar Kraut oma käsiraamatus "Eesti keele hääldamine" (Kraut 2000), nimetada võiks veel kahte artiklit vene aktsendi tunnusjoontest (Rannut 2000, 2003). Akustilisel analüüsil põhinev vene aktsendinähtude süstemaatiline käsitlus on seni puudunud, käesolev artikkel on sissejuhatuseks selle lünga täitmisel.

\section{Aktsendi olemusest}

Kuigi aktsent on kergesti tajutav, ei ole sellel korrektset definitsiooni. Üldiselt defineeritakse aktsenti kui kõrvalekallet keele normhääldusest. Kõrvalekaldeid normhääldusest võib kirjeldada nii kõnetaju kui ka -produktsiooni vaatevinklist. Primaarne on, et emakeelne kõneleja tajub aktsenti iseloomustavat kõrvalekallet, artikulatsiooniprotsessis esinevad erinevused on teisejärgulised. Ainult tajutud hälbeid võime kirjeldada kui aktsendinähtusi.

Aktsent võib olla nii fonoloogiline kui foneetiline. Fonoloogilise aktsendi korral on tegemist kognitiivsete piirangutega, mis on tingitud emakeele ja võõrkeele erinevast fonoloogiliste kategooriate süsteemist. Ilmekaks näiteks on jaapanlaste raskused eristada inglise keele foneeme /l/ ja /r/ (Yamada 1995), kuna nende emakeeles kuuluvad need foneemid samasse kategooriasse, inglise keeles aga on need eri fonoloogilised kategooriad.

Foneetilise aktsendi korral on võõrkeeleõppija omandanud küll korrektsed fonoloogilised kategooriad, kuid ei suuda produtseerida vastavat foneetilist väljundit. Tüüpiline näide saksa keelt õppivate ameeriklaste kõnes on foneemi /r/ realiseerimine [ I ]-na hääliku [ R ] asemel (nt saksakeelses sõnas grauem) (Jilka 2000).

Aktsent võib olla ka segmentaalne või prosoodiline. Esimesel juhul väljendub see häälikutasandil, nt sõnas /sata/ hääldatakse /t/ helilisena [d]. Prosoodilise aktsendi näiteks on emakeele lauseintonatsiooni ülekandmine võõrkeelsele sama tüüpi lausele.

Aktsendiga kõnes esinevad tavaliselt mitmed hälbed samaaegselt, kusjuures erinevatel hälvetel on aktsendi tajumisel erinev kaal. Aktsent on erinevat tüüpi 
hälvete kogum, mille analüüsimiseks ei piisa siiski ainult subjektiivsest tajuhinnangust, vaid on vajalik objektiivselt mõõta hälvete ulatust. Seega on aktsendi kirjeldamiseks oluline kombineerida tajuandmeid ja akustilise analüüsi abil saadud mõõtmistulemusi.

Teise keele omandamine on protsess, mida lisaks emakeelele mõjutavad ka neurofüsioloogilised ja sotsiaalpsühholoogilised tegurid. Võõrkeelse aktsendi teket ja olemust püüavad selgitada mitmed teooriad, mida järgnevas lühidalt esitletakse.

\section{Kriitilise perioodi hüpotees}

Keeleomandamise neurofüsioloogiliste protsesside uurimused on näidanud, et keele omandamisel mängivad olulist rolli vanuselised iseärasused. Üks tuntumatest teooriatest on kriitilise perioodi hüpotees (Critical Period Hypothesis (CPH), Lenneberg 1967), mis väidab, et keele omandamine emakeele tasemel on võimalik vaid noores eas. Sel perioodil on aju veel piisavalt plastiline ja võimeline kohanema õpitava keele spetsiifiliste struktuuridega, hilisemas eas aju kaotab sellise kohanemisvõime ja uue keele omandamine on vähem efektiivne. On väidetud, et selle põhjuseks on puberteediea algusega seotud aju plastilisuse muutused.

\section{Optimaalse kauguse mudel}

Sotsiaalpsühholoogilistest teguritest mõjutavad võorkeele omandamist õppija andekus, motivatsioon, isikuomadused, aga ka ümbritsev keelekeskkond ja emakeele ning sihtkeele kultuurilised suhted. Sotsiaalpsühholoogilistest mudelitest tuntuim on optimaalse kauguse mudel (Optimal Distance Model (ODM), Brown 1980), mis defineerib optimaalse perioodi võõrkeele omandamiseks, pidades sotsiaalpsühholoogilisi tegureid neurofüsioloogilistest olulisemakski. Mudelis ei ole sotsiaalkultuuriline kriitiline periood seotud õppija vanusega, vaid akulturatsiooniprotsessi etapiga, mil lähte- ja sihtkultuuride optimaalne kaugus loob soodsad tingimused ja vajaduse keele paremaks omandamiseks.

\section{Emakeele magnet-teooria}

Emakeele magnet-teooria (Native Language Magnet Theory (NLM), Kuhl 1991, Kuhl, Iverson 1995) selgitab teise keele omandamisega kaasneva võõrkeelse aktsendi teket kõnetaju eripäraga, mille kohaselt emakeele foneetilised kategooriad toimivad kui pertseptiivsed magnetid, põhjustades "kurtust" teise keele foneetiliste kategooriate suhtes. NLM-teooria aluseks on tajueksperimentide tulemused, mis näitavad, et sündides on imik võimeline kuuldeliselt eristama kõikvõimalikke häälikuid, kuid kokkupuutes emakeelega kujunevad imikueas välja emakeele hälikute prototüübid. Need prototüübid toimivad kui magnetid, mis tõmbavad ligi sama kategooria teisi realisatsioone, vähendades seega pertseptiivset kaugust prototüübi ja tajutava hääliku vahel.

\section{Kõne õppimise mudel}

Kõne õppimise mudel (Speech Learning Model (SLM), Flege 1995) keskendub põhiliselt võõrkeele häälduse täielikule omandamisele ja selle seosele õppija vanusega. Ka SLM lähtub eeldusest, et emakeele omandamisel kohaneb tajumehhanism emakeele foneetiliste kontrastidega ja võõrkeeleõppijatel on raskusi tajuda 
õpitava keele kategooriate erinevusi, kuna need võivad assimileeruda lähedaste emakeelsete kategooriatega. SLM seob võorkeelse aktsendi esinemise K2 foneetiliste kategooriate tajuga ja K2 õppimise east tingitud faktoritega.

\section{Pertseptiivse assimilatsiooni mudel}

Pertseptiivse assimilatsiooni mudel (Perceptual Assimilation Model (PAM), Best 1995) lähtub hüpoteesist, et kõnetaju ja -produktsiooni elementaarsed ühikud emakeele fonoloogilises ruumis on artikulatoorsed žestid. Mudeli kohaselt tajutakse võõrkeelseid kõnesegmente vastavalt nende sarnasusele ja erinevusele emakeele lähimast prototüübist.

\section{Ontogeneesi-fülogeneesi mudel (vahekeele mudel)}

Ontogeneesi-fülogeneesi mudeli (Ontogeny Phylogeny Model (OPM), Major 2001) keskne mõiste on vahekeel (interlanguage, IL) (Selinker 1972), s.o keel, mis iseloomustab täiskasvanud keeleõppija lingvistilist süsteemi. Vahekeeles on nii emakeele (K1), õpitava keele (K2) kui ka keeleuniversaalide (U) komponente. Vahekeel kujuneb K1 keelesüsteemi elementide ülekandmisel K2-le. Selline ülekanne võib olla nii positiivne kui negatiivne - positiivse ülekande puhul on K1 ja K2 elemendid samased ja aktsenti ei teki, negatiivse ülekande puhul aga erinevad ja tulemuseks on aktsent. Ülekanne võib leida aset kõigil keeletasanditel: leksikoni, fonoloogia, morfoloogia, süntaksi, semantika ja pragmaatika tasandil. Kui keeleõppija poolt tehtavad vead ei ole tingitud K1 ülekandest, siis pärinevad nad tõenäoliselt keeleuniversaalidest.

Ontogeneesi-fülogeneesi mudel on sisuliselt vahekeele evolutsiooni mudel.

\section{Eesmärgid ja metoodika}

Uurimuse eesmärk on analüüsida vene aktsendi akustilisi tunnuseid ja esitada erinevate aktsendinähtude kirjeldused akustiliste parameetrite kaudu. Lähtutakse eeldusest, et kui aktsent on tajutav, siis kajastub see ka mitmetes mõõdetavates akustilistes tunnustes. Aktsendiga kõnest mõõdetud tunnuste väärtuste võrdlemisel normkõne vastavate väärtustega arvutatakse tunnuste hälbed, mida võib käsitleda kui aktsenti iseloomustavaid kvantitatiivseid näitajaid. Emakeele magnet-efektist ja teistest aktsenditeooriatest (SLM, PAM, OPM) lähtuvalt tuleks akustiliste tunnuste hälvete põhjusi otsida eelkõige vene ja eesti keele fonoloogiliste süsteemide erinevusest.

Uurimus on osa ulatuslikumast vene aktsendi akustilisest analüüsist, selle eesmärgiks on eelkõige näidata, et aktsendinähtusi on võimalik kirjeldada erinevate akustiliste tunnuste abil, samuti välja pakkuda metoodika edasisteks põhjalikumateks uuringuteks. Esmased akustiliste mõõtmiste tulemused kajastavad väikese arvu keelejuhtide hääldust ja sellisena ei pretendeeri ühe või teise aktsendinähtuse ammendavale kirjeldusele. 


\subsection{Keelejuhid ja materjal}

Lähtudes ontogeneesi-fülogeneesi mudelist, uuritakse töös vahekeele akustilisi omadusi. Keelejuhtide valikul on eeldatud suhteliselt võrdset vahekeele arengustaadiumi - emakeeleks on kõigil vene keel, vanus 19-21 aastat, pärit Tallinnast ja Ida-Virumaalt (14 keelejuhti: 12 naist, 2 meest, TLÜ ja TTÜ üliõpilased). Kõik alustasid eesti keele õppimist vanuses 1-10 eluaastat (kriitilise perioodi hüpoteesi seisukohalt soodsas eas), lõpetasid venekeelse keskkooli ja uuringu ajal õppisid eestikeelses ülikoolis. Sotsiaalkultuuriliselt on Ida-Virumaalt pärit keelejuhid olnud vähemsoodsates tingimustes, kus igapäevane kokkupuude eesti keelega on oluliselt harvem kui Tallinnas. Kõigi keelejuhtide kõnes on tajutav vene aktsent.

Aktsendinähtude uurimiseks on kasutatud kõnekorpust, mis on salvestatud eestikeelse tekstikorpuse (koostanud E. Kraut) ettelugemisel. Korpuses on esindatud eesti vokaalid, diftongid, konsonandid ja konsonantühendid erinevates kontekstides - üksiksõnades ja lühikestes lausetes. Esindatud on erinevad silbija rõhustruktuurid ning välted, samuti erinevad lauseintonatsioonimallid.

Võrdlusmaterjaliks salvestati sama korpus ka eesti emakeelega keelejuhtidelt (1 naine - Urve Koni, Eesti Raadio diktor, 1 mees - Einar Kraut, Eesti Raadio kõnetehnika konsultant).

Aktsendiga kõne salvestused viidi läbi TTÜ Küberneetika Instituudi foneetika ja kõnetehnoloogia labori salvestusruumis, kasutades kondensaatormikrofoni Sony ECM-44B ning digitaalset magnetofoni Casio DA7. Mikrofoni kaugus keelejuhi huultest oli ca $20 \mathrm{~cm}$. Normhääldusega võrdlusmaterjal salvestati Eesti Raadio stuudios sarnase salvestustehnika abil. Salvestused sisestati arvutisse edasise töötluse ja akustilise analüüsi tarvis (diskreetimissagedus $16 \mathrm{kHz}$, resolutsioon 16 bitti).

\subsection{Analüüsi metoodika}

Aktsendiga kõnet analüüsiti järgnevate etappidena.

Pertseptiivne eksperthinnang - aktsendiga kõnesalvestusi hindas kaks eesti emakeelega eksperti, nende tajuotsustuste alusel valiti akustilise analüüsi tarvis välja need sõnad ja laused, mille puhul tajuti aktsenti vähemalt kahe keelejuhi kõnes. Samu sõnu analüüsiti ka normhääldusega keelejuhtide kõnes.

Segmenteerimine - analüüsiks valitud kõnenäited segmenteeriti sõna, silbi ja hääliku tasandil, selleks kasutati programmi Praat (versioon 4.2.15). Häälikupiiride leidmisel lähtuti eelkõige signaalikujust ja spektrogrammist ning auditiivsest informatsioonist. Silbipiirid lahtise silbi korral ühtivad vastavalt silbialguse konsonandi algusega ja viimase vokaali lõpuga. Geminaati sisaldavate sõnade korral on silbipiiri määramine keerukam: Q2 sõnade korral silbipiir poolitab geminaadi, Q3 sõnade korral on lähtutud seisukohast, et geminaadi teise osisfoneemi kestus on võrdne vastava osise kestusega Q2 sõnades ja seega asetatakse silbipiir teise osise algusesse (Eek, Meister 2004).

Akustiliste tunnuste analüüs - sõltuvalt aktsendinähtusest on mõõdetud või arvutatud erinevate akustiliste tunnuste väärtusi (programmi Praat abil), nt sõna temporaalstruktuuri kirjeldamiseks leiti häälikute ja silpide kestused, vokaalide kvaliteedi analüüsil mõõdeti nende formantsageduste väärtusi, sõnarõhu 
kirjeldamiseks analüüsiti rõhulise vokaali põhitooni ja intensiivsuse kontuure ning kestust jne. Hääliku- ja silbikestused on arvutatud segmenteerimisel määratud segmendipiiride alusel; formantsageduste väärtused on mõõdetud vokaalide keskosas, kus koartikulatsioonist tingitud formantide siirdefaas on lõppenud; intensiivsuse ja põhitooni sageduse puhul on mõõdetud nende tippväärtusi uuritavates segmentides.

Mõõtmisandmete statistiline analüüs ja interpreteerimine - mõõtmisandmete põhjal on arvutatud erinevate tunnuste keskmised väärtused ja standardhälbed eraldi aktsendiga ja aktsendita kõne kohta. Põhjalikum statistiline analüüs (nt ANOVA) ei ole uuritava materjali liialt piiratud mahu tõttu otstarbekas.

Normkõnest leitud tunnuste keskväärtused on nn referentsväärtused, millega võrreldakse aktsendiga kõne vastavaid väärtusi.

\section{Akustilise analüüsi tulemused}

\subsection{Temporaalse struktuuri hälbed}

Temporaalse struktuuri hälbed sõna piires kajastuvad eelkõige häälikute ja silpide ajalise kestuse ja kestussuhete oluliste kõrvalekalletena eesti keele normist. Järgnevalt kirjeldatakse kahe sõnatüübi - CVCV ja CVCCVC - temporaalset struktuuri, mille puhul on kõrvalekalded normkõnest enam tajutavad. Kuuldeliselt määratletuna on CVCV struktuuriga sõnades tegemist eelkõige rõhulise vokaali pikenemisega ja rõhutu vokaali lühenemisega ning geminaadi pikenemisega CVCCVC sõnades. Sageli kaasneb sellega silpide kestussuhte ulatuslik muutus, mis omakorda põhjustab vältemalli muutuse. Tüüpiline näide on II-vältelise kõnetakti hääldamine III vältes, nt sõnades koolis, kotid, kommid, kassad jt.

Eri kõnelejate erineva kõnetempo tõttu ei ole häälikute ja silpide absoluutsed kestused adekvaatselt võrreldavad. Kestusandmete võrdlemiseks on arvutatud iga hääliku kestuse osakaal sõnas.

CVCV-struktuuri korral on segmentide osakaalude keskmised väärtused arvutatud kaheksa sõna (/mita/ 'mida', /täti/ 'tädi', / piti/ 'pidi', /jüri/ 'Jüri', /kari/ 'kari', /veri/ 'veri', /vana/ 'vana', /valu/ 'valu') mõõteandmetest hääldatuna kahe K1 kõneleja (kokku 16 sõna) ja kolme kuni kuue K2 kõneleja poolt, kokku 38 sõna (tabel 1).

Tabel 1. Aktsendiga (K2) kõne segmentide proportsioonid ja standardhälbed võrrelduna aktsendita (K1) kõne segmentidega CVCV-tüüpi sõnades

\begin{tabular}{|l|l|l|l|l|}
\hline & C1 & V1 & C2 & V2 \\
\hline K2/K1 keskmine suhe & 1,09 & 1,42 & 0,88 & 0,75 \\
\hline Standardhälve & 0,08 & 0,16 & 0,17 & 0,1 \\
\hline
\end{tabular}




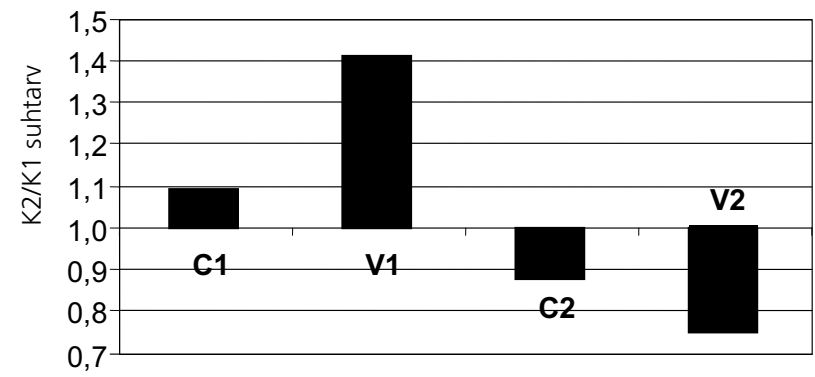

Joonis 1. K2 kõne segmentide proportsioonid võrrelduna K1 kõne segmentidega CVCV-tüüpi sõnades

Silbi alguskonsonantide osakaalud K2 kõnes ei erine oluliselt vastavatest väärtustest K1 kõnes: suhted $\mathrm{C}_{1}\left(\mathrm{~K}_{2}\right) / \mathrm{C} 1(\mathrm{~K} 1)=1,09$ ja $\mathrm{C}_{2}\left(\mathrm{~K}_{2}\right) / \mathrm{C} 2(\mathrm{~K} 1)=0,88$; seega on K2 konsonantide kestushälve ligikaudu 10\%. Kuid võrreldes vokaalide proportsioone K1 ja K2 kõnes, näeme, et K2 korral on rõhulise vokaali (V1) osakaal ca 1,4 korda suurem ja rõhutu vokaali (V2) osakaal 0,75 korda väiksem kui normkõnes (tabel 1, joonis 1).

CVCCVC-struktuuri korral on segmentide osakaalude keskmised väärtused arvutatud kuue sõna (/kottit/ 'kotid', /kassit/ 'kassid', /kassat/ 'kassad', /kommit/ 'kommid', /pannit/ 'pannid', /linnas/ 'linnas') mõõteandmetest hääldatuna kahe K1 kõneleja (kokku 12 sõna) ja kahe kuni kümne K2 kõneleja poolt, kokku 52 sõna (tabel 2).

Tabel 2. Aktsendiga (K2) kõne segmentide proportsioonid ja standardhälbed võrrelduna aktsendita (K1) kõne segmentidega CVCCVC-tüüpi sõnades

\begin{tabular}{|l|l|l|l|l|l|}
\hline \multicolumn{1}{|c|}{ C1 } & V1 & C2 & C2 & V2 & C3 \\
\hline K2/K1 keskmine suhe & 0,98 & 1,09 & 1,16 & 0,67 & 1,08 \\
\hline Standardhälve & 0,16 & 0,1 & 0,12 & 0,08 & 0,21 \\
\hline
\end{tabular}

K2 segmentide proportsioonid CVCCVC-struktuuri korral

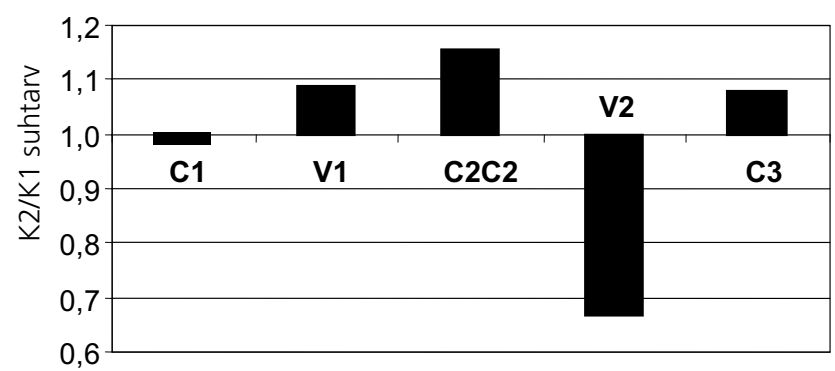

Joonis 2. K2 kõnesegmentide proportsioonid võrrelduna K1 kõnesegmentidega CVCCVC-tüüpi sõnades 
CVCCVC-struktuuri korral on sõnaalgulise konsonandi (C1) osakaalud K1 ja K2 kõnes peaaegu võrdsed (suhe 0,98). Esisilbi rõhulise vokaali (V1) ja sõnalõpukonsonandi ( 3 3) proportsioonid K2 kõnes on ligikaudu 10\% võrra suuremad kui K1 kõnes (suhtarvud vastavalt 1,09 ja 1,08). Suured temporaalse struktuuri hälbed esinevad aga geminaadi ( $\left.\mathrm{C}_{2} \mathrm{C}_{2}\right)$ ja rõhutu vokaali (V2) korral. Geminaadi (C2C2) osakaal K2 sõnades on 1,16 korda suurem ja järgsilbi vokaali (V2) osakaal o,67 korda väiksem võrreldes vastavate segmentide osakaaludega K1 kõnes (tabel 2, joonis 2).

\subsection{Silpide kestussuhted ja välted}

Taktivälte kontseptsiooni kohaselt on välte-haare takti rõhulise ja rõhutu silbi järjend, kusjuures välte määratlemisel osalevad mõlemad silbid. Väldete distinktiivsed kestusmallid põhinevad:

- $\quad$ rõhulise ja rõhutu silbi kestussuhetel (Eek, Meister 1997; Lehiste 1997) või siis

- $\quad$ taktisiseste naaberhäälikute kestussuhete erinevatel kombinatsioonidel (Eek, Meister 2003a; Eek, Meister 2004).

Kuna vene keele prosoodilises süsteemis eesti väldetele vastav nähtus puudub, siis võib eeldada, et vene emakeelega kõnelejatel on raske moodustada eri väldete tüüpilisi kestussuhteid.

Välteid iseloomustavad kestussuhted on leitud järgmiselt: kuna silbialgulised konsonandid ja rõhutu silbi kooda vältevastanduses rolli ei mängi, siis esmavältelise (Q1) struktuuri CVCV puhul taandub silpide kestussuhte arvutamine rõhulise ja rõhutu vokaali kestussuhte leidmisele; teisevältelise (Q2) struktuuri CVCCVC puhul leitakse silpide kestussuhe kui rõhulise silbi riimi ja rõhutu silbi tuuma kestuste suhe. Q2 taktis jaguneb geminaat võrdsetes osades rõhulise silbi kooda ja järgsilbi alguse vahel (Eek, Meister 2004). Seega arvutatakse riimi kestus kui rõhulise silbi tuuma (vokaal V1) ja kooda (pool geminaadist) kestuste summa.

Tabel 3. Silpide kestussuhted S1/S2 aktsendita (K1) ja aktsendiga (K2) kõnes

\begin{tabular}{|l|l|l|}
\hline & Q1 & Q2 \\
\hline$K 1$ & 0,7 & 1,6 \\
\hline$K 2$ & 1,3 & 2,6 \\
\hline
\end{tabular}

Leitud kestussuhteid on otstarbekas võrrelda mitmete autorite poolt varem avaldatud andmetega eesti välteid iseloomustavate kestussuhete kohta. Näeme, et aktsendita kõnest leitud Q1 ja Q2 kestussuhted (vt tabel 3: vastavalt o,7 ja 1,6) langevad hästi kokku kõigi varem avaldatud tulemustega (tabel 4).

Aktsendiga kõne Q1-le vastav kestussuhe $(1,3)$ on normkõnega võrreldes Q1 ja Q2 vahepealne, jäädes kahes varasemas töös esitatud Q2-le omase kestussuhte piiridesse (Krull 1991, 1992; Eek, Meister 1997). Q2 suhe aktsendiga kõnes (2,6) vastab Q3-le omasele suhtele normkõnes.

Saadud tulemused lubavad oletada, et eesti emakeelega kuulajad tajuvad aktsendiga kõnes esmavältelisi kõnetakte pigem teisevältelisena ja teisevältelisi pigem kolmandavältelisena. 
Tabel 4. Välteid iseloomustavad silpide kestussuhted (Eek, E. Meister 1997)

\begin{tabular}{|l|l|l|l|}
\hline & Q1 & Q2 & Q3 \\
\hline Lehiste 1960 & 0,7 & 1,5 & 2,0 \\
\hline Liiv 1961 & 0,7 & 1,6 & 2,6 \\
\hline Eek 1974 & 0,7 & 2,0 & 3,9 \\
\hline Krull 1991, 1992 & $0,5-0,7$ & $1,2-2,1$ & $2,2-2,9$ \\
\hline Eek, E. Meister 1997 & $0,4-0,7$ & $1,2-1,7$ & $2,5-4,6$ \\
\hline
\end{tabular}

\subsection{Sõnarõhk}

Eesti keeles eristatakse kolme rõhuastmega silpe: pearõhuline, kaasrõhuline ja rõhutu silp. Pearõhk tuuakse esile hingamis- ja häälduselundite jõulisema tegutsemisega ja tugevama hääldusintensiivsusega kui kaasrõhk. Pearõhk on tavaliselt esimesel silbil (välja arvatud võõrsõnad, hüüdsõnad ja mõned liitsõnad) (Eek, Meister 2004: 253). Vene keeles on rõhk liikuv, see võib asetseda esimesel, teisel jne silbil (голова́, го́ловъ, голо́вка). Kuid on ka sõnu, kus rõhk asetseb eri sõnavormide puhul alati ühel ja samal silbil (тоска́, тоски́, тоско́ŭ).

Sõnarõhuvead aktsendiga kõnes esinevad eelkõige sellistes sõnades, mis on sarnased mõlemas keeles (tabel 5). Põhiliselt on tegemist võõrsõnadega, mis on eesti keelesüsteemis kodunenud. Sagedam viga on emakeelele omase rõhu asukoha ülekandmine eestikeelsele sõnale.

Tabel 5. K2 kõnelejate tüüpilised rõhuvead (tumedalt trükitud häälik näitab rõhu asukohta)

\begin{tabular}{|l|l|l|}
\hline Keelejuht & Sõna eesti keeles & Sõna vene keeles \\
\hline 6 & bioloog & биолог \\
\hline 2 & neuronid & нейроны \\
\hline 1 & ešelon & эшелон \\
\hline 2 & protokoll & протокол \\
\hline 2 & psühholoog & психолог \\
\hline 4 & karneval & карнавал \\
\hline 2 & kartoteek & картотека \\
\hline 5 & apteek & аптека \\
\hline 9 & anekdoot & анекдот \\
\hline 11 & röntgen & рентген \\
\hline 6 & astronoom & астроном \\
\hline 6 & instrument & инструмент \\
\hline 5 & martsipan & марципан \\
\hline 9 & eksemplar & экземпляр \\
\hline
\end{tabular}

Vene keeles on rõhk seotud eelkõige kestusega - rõhuline silp on pikem kui rõhutu silp (Bondarko 1977), eesti keeles on sõnarõhu peamisteks korrelaatideks põhitooni sagedus ja intensiivsus (Eek, Meister 2004). 
Järgnevalt vaatleme sõnarõhu akustilisi korrelaate aktsendiga kõnes ühe sõna - apteeki (lausest Abt läks apteeki.) - näitel. Joonisel 3 on esitatud sõna apteeki helilaine, põhitooni sageduse (ülemine) ja intensiivsuse (alumine) kõverad aktsendivaba häälduse korral (vertikaalsed punktiirjooned tähistavad häälikupiire). Sellest nähtub, et rõhulise silbi vokaali põhitooni sagedus ja intensiivsus on oluliselt suuremad rõhutu silbi vokaali vastavatest parameetritest - tänu sellele tajutaksegi rõhku esisilbil.

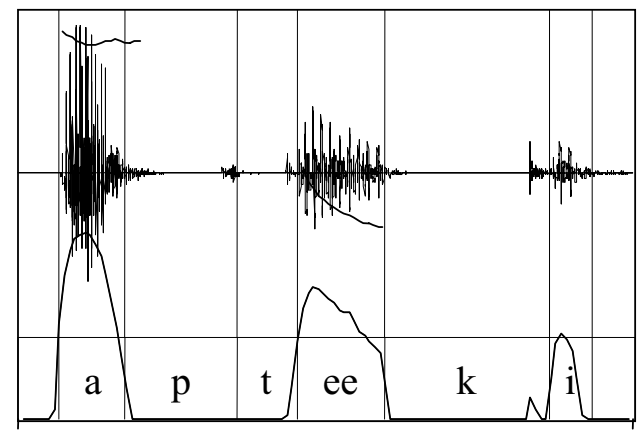

0.05

\section{Time (s)}

Joonis 3. Häälikute piirid helilaines (vertikaalsed punktiirjooned) ja põhitooni sageduse (ülemised kõverad vokaalisegmentides) ning intensiivsuse (alumine) kõverad aktsendivaba häälduse korral. Sõna apteeki lauses Abt läks apteeki. Keelejuht UK

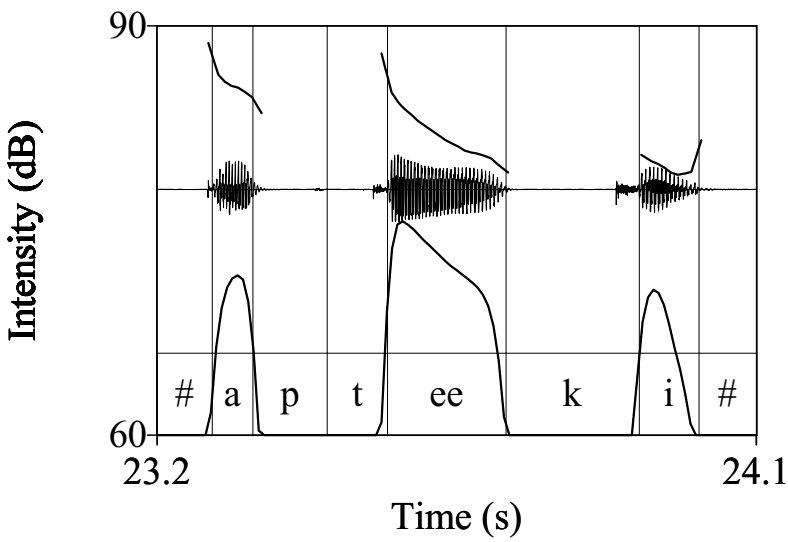

Joonis 4. Häälikute piirid helilaines (vertikaalsed punktiirjooned) ja põhitooni sageduse (ülemised kõverad vokaalisegmentides) ning intensiivsuse (alumine) kõverad aktsendiga häälduse korral. Sõna apteeki lauses Abt läks apteeki. Keelejuht 3

Joonisel 4 on esitatud sama sõna helilaine ja samade akustiliste parameetrite kõverad aktsendiga hääldatud sõnas, mille puhul rõhulisena tajutakse teist silpi. Näeme, et teise silbi vokaali kestus on tunduvalt suurem ja intensiivsushari kõrgem kui esimese vokaali puhul; põhitoonikontuur on mõlema vokaali puhul 
langev, kusjuures esimese vokaali keskmine põhitoon pisut kõrgem kui teisel vokaalil.

Et selline hääldus on vene aktsendile iseloomulik, näitavad tabelis 6 esitatud akustiliste mõõtmiste tulemused.

Tabel 6. Esimese ja teise silbi vokaalide kestus, intensiivsus ja põhitooni sageduse FO muutus sõnas apteeki aktsendiga (keelejuhid 1, 2, 3 ja 7) ning aktsendita (keelejuhid UK ja EK) kõnes

\begin{tabular}{|c|c|c|c|c|c|c|c|c|c|c|c|c|}
\hline & \multicolumn{2}{|c|}{\begin{tabular}{|l|} 
Keelejuht \\
1 \\
\end{tabular}} & \multicolumn{2}{|c|}{\begin{tabular}{|l} 
Keelejuht \\
2 \\
\end{tabular}} & \multicolumn{2}{|c|}{\begin{tabular}{|l} 
Keelejuht \\
$\mathbf{3}$ \\
\end{tabular}} & \multicolumn{2}{|c|}{\begin{tabular}{|l} 
Keelejuht \\
7
\end{tabular}} & \multicolumn{2}{|c|}{\begin{tabular}{|l} 
Keelejuht \\
UK
\end{tabular}} & \multicolumn{2}{|c|}{\begin{tabular}{|l} 
Keelejuht \\
EK \\
\end{tabular}} \\
\hline & /a/ & /ee/ & /a/ & /ee/ & $/ \mathrm{a} /$ & /ee/ & $/ \mathrm{a} /$ & /ee/ & $/ a /$ & /ee/ & $/ \mathrm{a} /$ & /ee/ \\
\hline Kestus, ms & 42 & 161 & 53 & 162 & 61 & 178 & 53 & 136 & 72 & 135 & 76 & 151 \\
\hline $\begin{array}{l}\text { Intensiivsus- } \\
\text { hari, dB }\end{array}$ & 68 & 74 & 70 & 67 & 71 & 75 & 68 & 66 & 79 & 75 & 82 & 75 \\
\hline $\begin{array}{l}\text { F0 muutus } \\
\text { vokaali } \\
\text { kestel, Hz }\end{array}$ & $\begin{array}{l}206 \\
\vdots \\
201\end{array}$ & $\begin{array}{l}211 \\
\searrow \\
176 \\
\end{array}$ & $\begin{array}{l}226 \\
y \\
212 \\
\end{array}$ & $\begin{array}{l}184 \\
\searrow \\
173 \\
\end{array}$ & $\begin{array}{l}217 \\
\vdots \\
209\end{array}$ & $\begin{array}{l}209 \\
\searrow \\
166\end{array}$ & $\begin{array}{l}256 \\
\searrow \\
235\end{array}$ & $\begin{array}{l}202 \\
\searrow \\
184 \\
\end{array}$ & $\begin{array}{l}159 \\
7 \\
155 \\
\end{array}$ & $\begin{array}{l}104 \\
\searrow \\
76\end{array}$ & $\begin{array}{l}129 \\
7 \\
130 \\
\end{array}$ & $\begin{array}{l}81 \\
\searrow \\
66\end{array}$ \\
\hline
\end{tabular}

Vokaalide /a/ ja /ee/ kestuste võrdlus näitab, et normkõnes on esisibi vokaali kestus keskmiselt ca 20 ms pikem ja teise silbi kestus keskmiselt ca 15 ms lühem kui aktsendiga kõnes. Vokaalide kestussuhted on veelgi ilmekamad: normkõnes on teise vokaali kestus peaaegu kaks korda suurem kui esimese vokaali kestus, aktsendiga kõnes on see suhe keskmiselt 3,o.

Analüüsides intensiivsuste väärtusi, näeme, et aktsendita keelejuhtide häälduses on esimene vokaal 4-7 dB võrra intensiivsem, aktsendiga kõne puhul käitub intensiivsus erinevalt - keelejuhtide 2 ja 7 puhul on /a/ intensiivsushari 2-3 dB võrra kõrgem kui /ee/ puhul, keelejuhtide 1 ja 3 puhul on olukord vastupidine, st teine vokaal on esimesest vastavalt 6 ja $4 \mathrm{~dB}$ võrra intensiivsem.

Põhitooni kulg aktsendiga ja aktsendita kõnes on erinev eelkõige esimese vokaali puhul - kui normkõnes põhitooni sagedus esimese vokaali jooksul pisut tõuseb, siis aktsendiga kõnes on jälgitav langus $5 \mathrm{~Hz}$ (keelejuht 1) kuni $21 \mathrm{~Hz}$ (keelejuht 7). Teise vokaali puhul on põhitooni kontuur kõigi keelejuhtide häälduses langev: 11-43 Hz aktsendiga kõne puhul ja 15-28 Hz normkõne puhul. Arvutades tabeli 6 andmetest lähtuvalt põhitooni sageduse keskmised väärtused /a/ ja /ee/ puhul, näeme, et normkõnes on see vahe keskmiselt $60 \mathrm{~Hz}$ ringis, aktsendiga kõnes aga keskmiselt $30 \mathrm{~Hz}$ lähedal.

Saadud andmed näitavad, et aktsendiga kõnes realiseeritakse sõnarõhk K1pärase akustilise tunnuse - kestuse - abil, intensiivsus ja põhitoon on sõnarõhu sekundaarsed korrelaadid, mille kasutamises esineb individuaalseid erinevusi. Sõnarõhu esiletoomine kestuse abil on ka eespool kirjeldatud temporaalse struktuuri hälvete põhiliseks põhjuseks. 


\subsection{Vokaalide formantsagedused}

Vokaali kvaliteedi määravad spektri maksimumide - formantide - asukohad. Kvaliteedi kirjeldamiseks mõõdetakse kuni nelja formandi sagedust, kuid olulisimad on kaks esimest. Eesti keele vokaaliruum jaguneb 9 vokaali (fonoloogilise kategooria) vahel, vene keele puhul on tegemist 6 vokaaliga, millest /и, е, a, o, у/ langevad küllalt hästi kokku vastavate eesti vokaalidega, kuid /ы/ kvaliteet on küllalt erinev. Seega on vene keele puhul iga vokaali jaoks justkui rohkem ruumi ja nende hääldus ei pea olema nii täpne. Eesti vokaalide hääldamisel on vajalik suurem täpsus, mille omandamine võib olla venelastele probleemiks. Sisuliselt tähendab see nelja uue fonoloogilise kategooria /ä, ö, ü, õ/ omandamist. Vokaalide asetus formantsageduste F1-F2 ruumis võimaldab hinnata, kui hästi on K2 kõnelejad need uued kategooriad omandanud.

Järgnevalt on esitatud eesti vokaalide formantsageduste väärtused K1 ja K2 kõnes (tabel 7 ja 8) ning vastavate vokaaliruumide graafikud (joonis 5,6 ja 7, 8).

Tabel 7. Rõhuliste ja rõhutute vokaalide keskmised formantsagedused ja standardhälbed eesti normkõnes (keelejuht UK). N on mõõdetud vokaalide arv

\begin{tabular}{|c|c|c|c|c|c|c|c|}
\hline & \multicolumn{3}{|c|}{ Rõhulised vokaalid } & \multicolumn{3}{|c|}{ Rõhutud vokaalid } \\
\hline & & $\mathrm{F} 1, \mathrm{~Hz}$ & $\mathrm{~F} 2, \mathrm{~Hz}$ & $\mathrm{~N}$ & $\mathrm{~F} 1, \mathrm{~Hz}$ & $\mathrm{~F} 2, \mathrm{~Hz}$ & $\mathrm{~N}$ \\
\hline \multirow{2}{*}{ /i/ } & Keskmine & 329 & 2757 & \multirow{2}{*}{6} & 352 & 2532 & \multirow{2}{*}{8} \\
\hline & St. hälve & 47 & 119 & & 66 & 198 & \\
\hline \multirow{2}{*}{ /e/ } & Keskmine & 473 & 2418 & \multirow{2}{*}{5} & 665 & 2085 & \multirow{2}{*}{9} \\
\hline & St. hälve & 57 & 153 & & 113 & 204 & \\
\hline \multirow{2}{*}{ /ä/ } & Keskmine & 790 & 1732 & \multirow{2}{*}{5} & - & - & \multirow{2}{*}{-} \\
\hline & St. hälve & 45 & 209 & & - & - & \\
\hline \multirow{2}{*}{ /ü/ } & Keskmine & 360 & 2078 & \multirow{2}{*}{4} & - & - & \multirow{2}{*}{-} \\
\hline & St. hälve & 43 & 192 & & - & - & \\
\hline \multirow{2}{*}{ /Ö/ } & Keskmine & 475 & 1756 & \multirow{2}{*}{4} & - & - & \multirow{2}{*}{-} \\
\hline & St. hälve & 63 & 118 & & - & - & \\
\hline \multirow{2}{*}{$/ \mathrm{u} /$} & Keskmine & 364 & 735 & \multirow{2}{*}{5} & 382 & 1053 & \multirow{2}{*}{7} \\
\hline & St. hälve & 39 & 85 & & 35 & 120 & \\
\hline \multirow{2}{*}{ /o/ } & Keskmine & 483 & 925 & \multirow{2}{*}{5} & 570 & 1122 & \multirow{2}{*}{6} \\
\hline & St. hälve & 40 & 84 & & 96 & 115 & \\
\hline \multirow{2}{*}{ /õ/ } & Keskmine & 424 & 1291 & \multirow{2}{*}{5} & - & - & \multirow{2}{*}{-} \\
\hline & St. hälve & 111 & 100 & & - & - & \\
\hline \multirow{2}{*}{ /a/ } & Keskmine & 736 & 1120 & \multirow{2}{*}{7} & 723 & 1320 & \multirow{2}{*}{8} \\
\hline & St. hälve & 67 & 149 & & 69 & 80 & \\
\hline
\end{tabular}


Tabel 8. Rõhuliste ja rõhutute vokaalide keskmised formantsagedused ja standardhälbed aktsendiga kõnes (neli K2 naiskeelejuhti). N on mõõdetud vokaalide arv

\begin{tabular}{|c|c|c|c|c|c|c|c|}
\hline & \multicolumn{3}{|c|}{ Rõhulised vokaalid } & \multicolumn{3}{|c|}{ Rõhutud vokaalid } \\
\hline & & $\mathrm{F} 1, \mathrm{~Hz}$ & $\mathrm{~F} 2, \mathrm{~Hz}$ & $\mathrm{~N}$ & $\mathrm{~F} 1, \mathrm{~Hz}$ & $\mathrm{~F} 2, \mathrm{~Hz}$ & $\mathrm{~N}$ \\
\hline \multirow{2}{*}{ /i/ } & Keskmine & 450 & 2718 & \multirow{2}{*}{53} & 490 & 2437 & \multirow{2}{*}{68} \\
\hline & St. hälve & 56 & 109 & & 59 & 229 & \\
\hline \multirow{2}{*}{ /e/ } & Keskmine & 559 & 2368 & \multirow{2}{*}{32} & 6625 & 1986 & \multirow{2}{*}{78} \\
\hline & St. hälve & 46 & 161 & & 85 & 216 & \\
\hline \multirow{2}{*}{ /ä/ } & Keskmine & 745 & 1752 & \multirow{2}{*}{57} & - & - & \multirow{2}{*}{-} \\
\hline & St. hälve & 53 & 263 & & - & - & \\
\hline \multirow{2}{*}{ /ü/ } & Keskmine & 476 & 1918 & \multirow{2}{*}{45} & - & - & \multirow{2}{*}{-} \\
\hline & St. hälve & 53 & 355 & & - & - & \\
\hline \multirow{2}{*}{ /ö/ } & Keskmine & 550 & 1827 & \multirow{2}{*}{26} & - & - & \multirow{2}{*}{-} \\
\hline & St. hälve & 54 & 140 & & - & - & \\
\hline \multirow{2}{*}{$/ u /$} & Keskmine & 451 & 889 & \multirow{2}{*}{55} & 483 & 1079 & \multirow{2}{*}{53} \\
\hline & St. hälve & 59 & 162 & & 60 & 200 & \\
\hline \multirow{2}{*}{ /o/ } & Keskmine & 544 & 1008 & \multirow{2}{*}{61} & 561 & 1209 & \multirow{2}{*}{43} \\
\hline & St. hälve & 52 & 182 & & 51 & 236 & \\
\hline \multirow{2}{*}{ /õ/ } & Keskmine & 470 & 1779 & \multirow{2}{*}{48} & - & - & \multirow{2}{*}{ - } \\
\hline & St. hälve & 63 & 494 & & - & - & \\
\hline \multirow{2}{*}{ /a/ } & Keskmine & 759 & 1277 & \multirow{2}{*}{75} & 685 & 1382 & \multirow{2}{*}{75} \\
\hline & St. hälve & 77 & 108 & & 82 & 168 & \\
\hline
\end{tabular}

$\mathbf{F} 2, \mathrm{~Hz}$

K1 kõneleja rõhuliste vokaalide asetus

3000

25002000

1500

1000

500

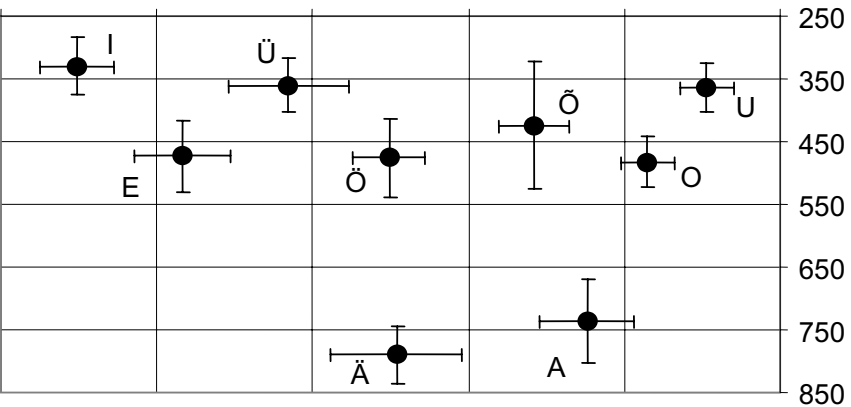

Joonis 5. Rõhuliste vokaalide asukohad $(\bullet)$ ja formantsageduste standardhälbed K1 kõneleja (keelejuht UK) vokaaliruumis 
F2, Hz

K1 kõneleja rõhuliste ja rõhutute vokaalide asetus

3000

2500

2000

1500

1000

500

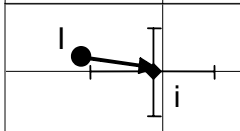

Ü

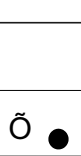

E

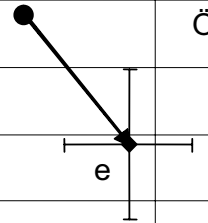

Ö

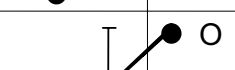

450

550 运

650

750

$\ddot{A}$

850

Joonis 6. Rõhuliste $(\bullet)$ ja rõhutute $(\bullet)$ vokaalide asukohad ning rõhutute vokaalide formantsageduste standardhälbed K1 kõneleja (keelejuht UK) vokaaliruumis

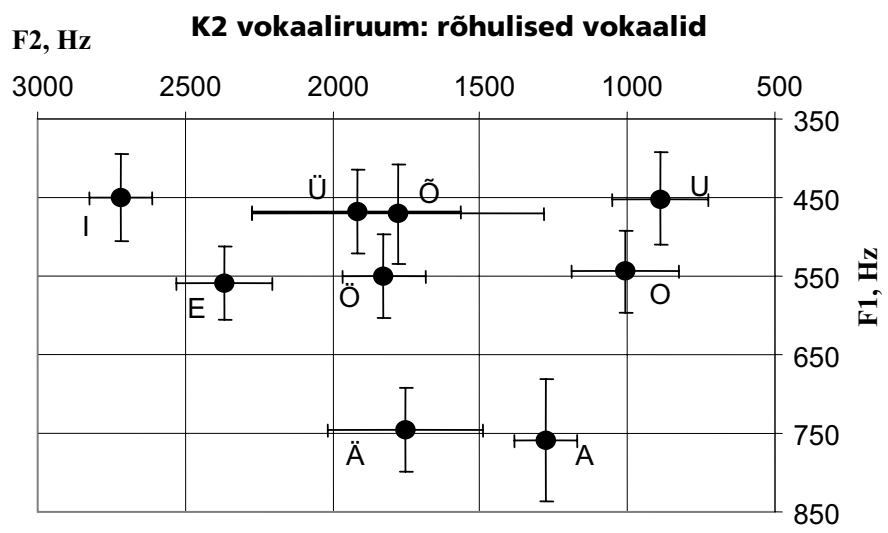

Joonis 7. Rõhuliste vokaalide asukohad $(\bullet)$ ja formantsageduste standardhälbed K2 kõnele omases vokaaliruumis

$\mathrm{F} 2, \mathrm{~Hz} \quad \mathrm{~K} 2$ vokaaliruum: rõhulised ja rõhuta vokaalid

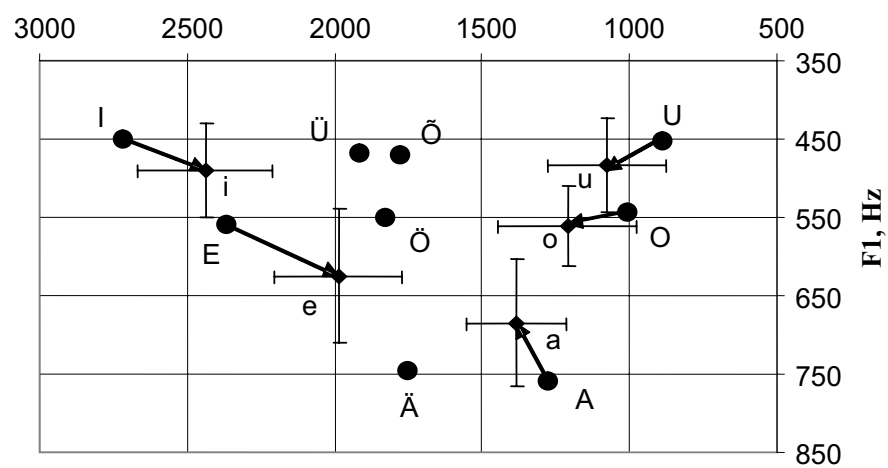

Joonis 8. Rõhuliste $(\bullet)$ ja rõhutute $(\bullet)$ vokaalide asukohad ning rõhutute vokaalide formantsageduste standardhälbed K2 kõnele omases vokaaliruumis 
Saadud tulemused näitavad (vrd joonis 5 ja 7), et K2 kõnele omases vokaaliruumis asuvad rõhulised vokaalid /i, e, a, o, u/ normkõnele lähedastes positsioonides, /ä/ on pisut kõrgenenud, /ö/ ja / ̈̈/ on tagapoolsemad ja /õ/ on eespoolsem võrreldes K1-le omaste asenditega. /õ/ ja / ̈̈/ teise formandi sageduse suur standardhälve viitab nende vokaalide kvaliteedi suurele variatiivsusele.

Rõhututele vokaalidele on nii K1 kui K2 kõnes omane nihkuda vokaaliruumi keskpunkti suunas ja suuri kvaliteedihälbeid käesolevas andmestikus ei esine.

\subsection{Diftongi komponentide kestused}

Eesti kirjakeeles on 36 diftongi. Diftongi esikomponendiks võib olla mis tahes vokaal, järelkomponendiks /a, e, i, u, o/, teise komponendina ei esine kirjakeeles /ä, ö, ü, õ/. Vene keeles esinevad vokaaliühendid ainult laensõnades või morfeemipiiril, kuid mitte ühes ja samas silbis (хаос, Диана, неудача). Seega eesti diftongidega võrreldavad ühendid vene keeles puuduvad.

Diftongikomponentide kestussuhted (V2/V1) eesti normkõnes kõiguvad ühtedel andmetel vahemikus 1,1-1,33 (Piir 1985), teistel andmetel on teisevältelistes sõnades (/lauta/ 'laut', gen. sg., Q2) V2/V1 = 0,7-0,8 ja kolmandavältelistes sõnades (/lau:ta/ 'laud', part. sg., Q3) V2/V1 = 1,4-1,5 (Eek, Meister 2003b).

Aktsendiga kõnest mõõdetud diftongiosiste keskmised kestused erinevate sõnatüüpide ja väldete korral on ligikaudu võrdsed, varieerudes vahemikus 0,951,03 (tabel 9, K2 andmed). Ootuspäraselt on K1 kõnes diftongikomponentide kestussuhete erinevused suuremad: Q2 sõnade korral on suhe 1,1, Q3 ühesilbiliste sõnade korral 1,3 ja Q3 kahesilbiliste sõnade korral 1,4 (tabel 9, K1 andmed).

Diftongi komponentide kestuste ja välte seosed K2 kõnes vajavad põhjalikumat uurimist nii akustiliselt kui ka pertseptiivselt.

\subsection{Diftongi komponentide formantsagedused}

Diftongi korrektseks tuvastamiseks arvatakse olevat vajalik eelkõige selle esikomponendi kvaliteet ja formantide liikumise trajektoor teise komponendi sihtväärtuse suunas, kuid viimase saavutamine polegi oluline (Pols 1977). Seega võib oletada, et diftongi esikomponendi kvaliteet on lähedane vastava üksikvokaali kvaliteedile rõhulises positsioonis, kuid teine komponent ei pruugi saavutada vastava vokaali sihtväärtust ja võib olla seetõttu kvaliteedilt ebamäärasem.

Uuritavas materjalis esineb diftongide häälduses mitmeid vokaali-kvaliteedi probleeme, eelkõige nende vokaalide puhul, mida vene keeles ei leidu, samuti on vene emakeelega kõnelejale harjumatud artikulatoorsed liigutused ühelt vokaalilt teisele.

Pertseptiivselt on normist enam hälbivad diftongide hääldused järgmistes sõnades: jõel (joonis 9), sõelaga, õige,jõuame, söanda, pöaksin, öeldakse, käiakse jt. Formantsageduste mõõtmisandmed diftongides vajavad veel põhjalikku töötlust, seetõttu neid käesolevas artiklis ei esitata. Järgnev joonis 9 iseloomustab diftongide häälduses esinevaid hälbeid. 
Tabel 9. Diftongikomponentide keskmised kestussuhted aktsendiga ( $K 2$, kuus keelejuhti)) ja aktsendita (K1, kaks keelejuhti) kõnes ühe- (A), kahe- (B, Q3 sõnad; C, Q2 sõnad) ja kolmesilbilistes (D, Q2 sõnad) sõnades

\begin{tabular}{|c|c|c|c|}
\hline \multirow{2}{*}{\multicolumn{2}{|c|}{ Diftongid sõnades }} & \multirow{3}{*}{\begin{tabular}{|l|}
$\mathbf{K} 2$ \\
$\mathrm{~V} 2 \mathrm{~N} 1$ \\
1,12 \\
\end{tabular}} & \multirow{3}{*}{\begin{tabular}{|l|}
$\mathbf{K 1}$ \\
$\mathrm{V} 2 \mathrm{~N}$ \\
1,38 \\
\end{tabular}} \\
\hline & & & \\
\hline \multirow{7}{*}{ A } & jõel & & \\
\hline & laost & 0,69 & 1,13 \\
\hline & laul & 0,86 & 1,47 \\
\hline & peol & 1,17 & 1,29 \\
\hline & soust & 1,13 & 1,16 \\
\hline & Keskmine & 1,00 & 1,29 \\
\hline & Standardhälve & 0,21 & 0,14 \\
\hline \multirow{6}{*}{$B$} & noaga & 0,85 & 1,42 \\
\hline & näoga & 0,95 & 1,27 \\
\hline & oige & 1,14 & 1,49 \\
\hline & öine & 0,86 & 1,36 \\
\hline & Keskmine & 0,95 & 1,38 \\
\hline & Standardhälve & 0,13 & 0,09 \\
\hline \multirow{10}{*}{ C } & hoian & 1,27 & 1,21 \\
\hline & koerad & 0,77 & 0,94 \\
\hline & linad & 1,16 & 1,15 \\
\hline & päevad & 0,64 & 0,83 \\
\hline & pöial & 1,12 & 1,26 \\
\hline & reuma & 0,98 & 1,19 \\
\hline & saiad & 1,12 & 1,24 \\
\hline & veame & 0,96 & 1,26 \\
\hline & Keskmine & 1,00 & 1,13 \\
\hline & Standardhälve & 0,21 & 0,16 \\
\hline \multirow{7}{*}{ D } & jõuame & 1,38 & 1,26 \\
\hline & kräunatas & 0,90 & 1,15 \\
\hline & käiakse & 1,04 & 1,25 \\
\hline & Puiatus & 0,91 & 1,13 \\
\hline & sõelaga & 0,91 & 0,91 \\
\hline & Keskmine & 1,03 & 1,14 \\
\hline & Standardhälve & 0,21 & 0,14 \\
\hline
\end{tabular}



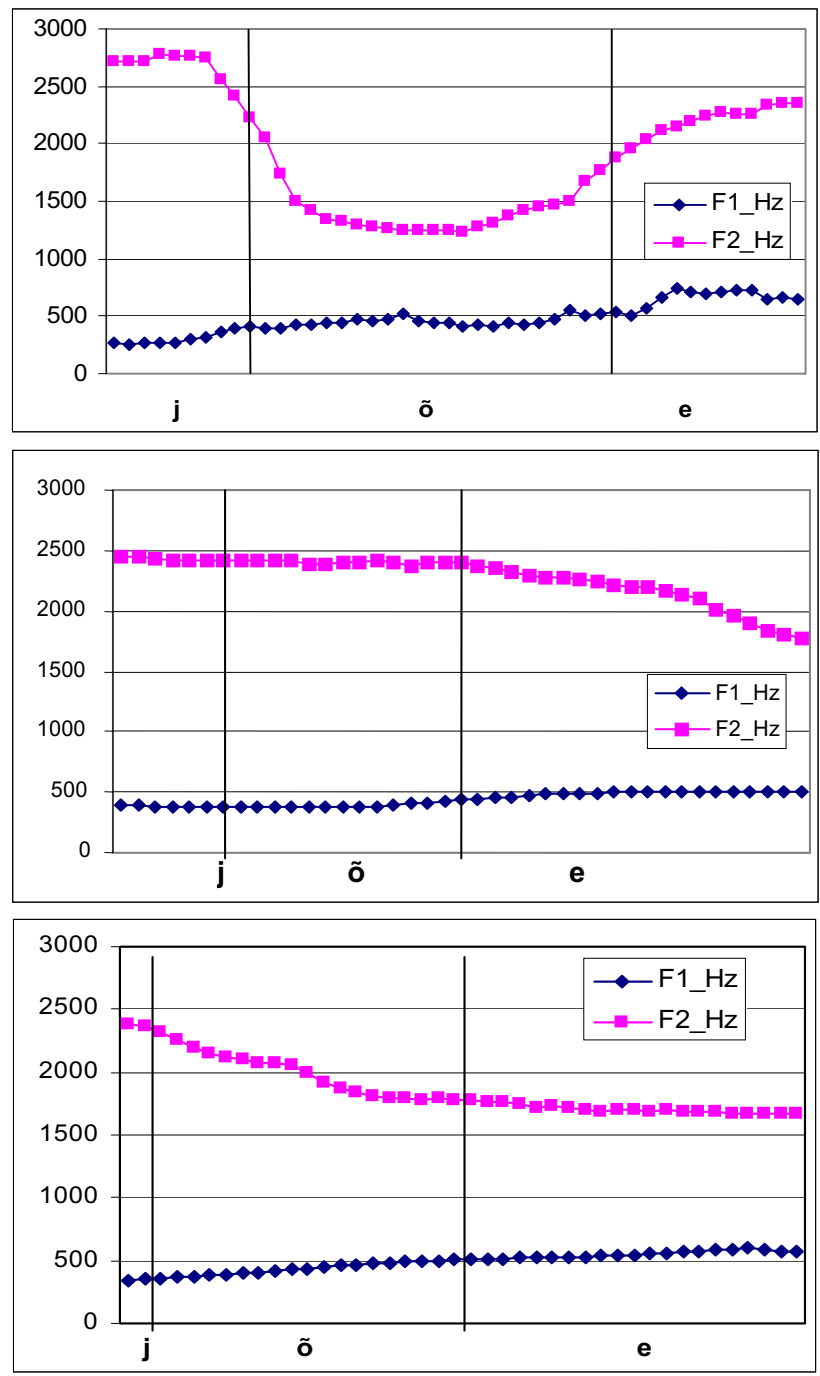

Joonis 9. Diftongi /õe/ formantsageduste F1 ja F2 trajektoorid sõnas jõe/.

Ülemine: K1 kõneleja (keelejuht UK), keskmine ja alumine: K2 kõnelejad (keelejuhid 10 ja 4) 


\subsection{Helilisus/helitus}

Vene keeles on lühikesed klusiilid helilised ja selline hääldusviis kantakse sageli üle ka vastavate eesti klusiilide /k, p, t/ hääldusele (vrd joonis 10A ja 10B).

A
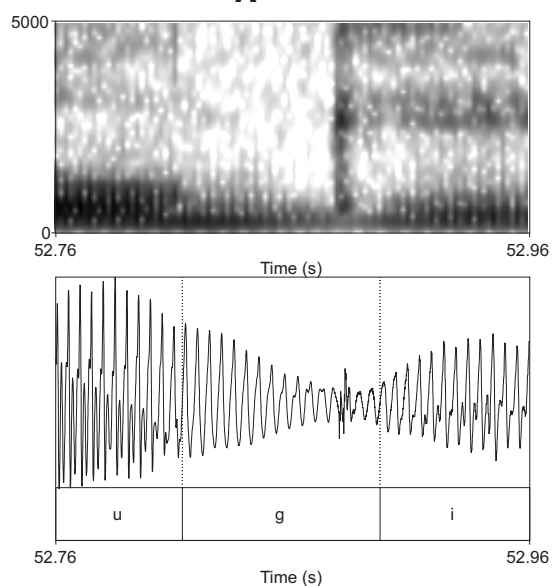

B

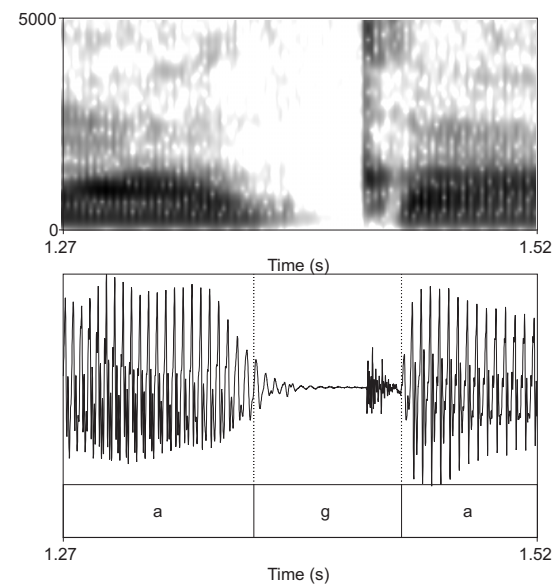

Joonis 10. Venepärane (A) ja eesti normkõnele vastav (B) klusiili /k/ hääldus

Tabelis 10 on esitatud andmed sõnasiseste silbialgusklusiilide (2. või 3. silp) kestuste kohta. K1 kõnelejate puhul oli tegemist eranditult helitute klusiilidega, vaid mõnel üksikul juhul esines klusiili osalist helilisustumist (kuni 2/3 sulufaasi kestusest). K2 keelejuhtidest mõõdeti kestused 6 kõneleja (keelejuhid 1, 2, 3, 4, 6, 10) puhul. Klusiilide häälduses esines suuri individuaalseid erinevusi, nt keelejuhi 1 ja keelejuhi 10 kõnes olid peaaegu kõik klusiilid helilised; keelejuhi 2 puhul olid /p/ ja /t/ enamuses helilised, kuid /k/ põhiliselt helitu; keelejuhi 3 hääldus oli lähedane K1 kõnelejate hääldusele, st peaaegu kõik klusiilid hääldati helitutena; keelejuhtide 4 ja 6 kõnes esines helilisi ja helituid hääldusvariante peaaegu võrdselt.

Tabel 10. Heliliste ja helitute sõnasiseste lühikeste klusiilide kestusandmed. $\mathrm{N}$ on analüüsitud sõnade arv

\begin{tabular}{|c|c|c|c|c|c|c|c|}
\cline { 3 - 9 } \multicolumn{2}{c|}{} & \multicolumn{3}{c|}{ K2 (6 keelejuhti) } & \multicolumn{3}{c|}{ K1 (2 keelejuhti) } \\
\cline { 3 - 9 } \multicolumn{2}{c|}{} & Kestus, ms & St. hälve & N & Kestus, ms & St. hälve & N \\
\hline \multirow{3}{*}{ Helitu } & $\mathrm{b}$ & 82 & 14 & 14 & 74 & 17 & 12 \\
\cline { 2 - 9 } & $\mathrm{d}$ & 83 & 19 & 24 & 73 & 16 & 24 \\
\cline { 2 - 9 } & $\mathrm{g}$ & 91 & 22 & 43 & 85 & 20 & 24 \\
\hline \multirow{3}{*}{ Heliline } & $\mathrm{b}$ & 70 & 14 & 23 & - & - & - \\
\cline { 2 - 9 } & $\mathrm{d}$ & 65 & 14 & 48 & - & - & - \\
\cline { 2 - 9 } & $\mathrm{g}$ & 67 & 18 & 29 & - & & \\
\hline
\end{tabular}

K2 klusiilide kestuste keskmised väärtused on arvutatud eraldi heliliste ja helitute realisatsioonide kohta. Helilised realisatsioonid on keskmiselt 12-24 ms lühemad kui vastavad helitud variandid. 
Näeme, et ka klusiilide hääldusele aktsendiga kõnes on sageli omane K1 hääldusmalli ülekandmine eesti keelde.

\section{Kokkuvõte}

Emakeelsed tavakuulajad tunnevad võõrkeelse aktsendi ära küllalt kergesti, kuid tavaliselt ei osata kuigi täpselt kirjeldada, mis oli aktsendiga kõnes hääldatud valesti. Veel vähem osatakse öelda, millise akustilise tunnuse hälve tingib ühe või teise aktsendinähtuse. Vene aktsendi senised kirjeldused on toetunud eelkõige uurijate tajuhinnangutele, mis paratamatult on subjektiivsed ja deskriptiivset laadi.

Artiklis esitatud akustilise analüüsi esmased tulemused näitavad, et vene aktsent eesti keeles avaldub kombinatsioonina erinevatest akustilistest tunnustest, millest olulisemad on temporaalse struktuuri ja rõhuparameetrite ning häälikute kvaliteediga seotud tunnuste hälbed.

Aktsendinähtude põhjused peituvad nii teise keele omandamise mehhanismis, mille kohaselt leiab võõrkeele õppimisel aset K1 keelesüsteemi elementide ülekanne õpitavasse keelde, kui ka eesti ja vene keele fonoloogiliste süsteemide erinevustes:

- $\quad$ temporaalse struktuuri hälbed aktsendiga kõnes on tingitud kestuse erinevast rollist eesti ja vene keeles. Eesti keeles on kestus fonoloogiline, eristades lühikesi ja pikki häälikuid; segmentide kestussuhted mängivad olulist rolli väldete tuvastamisel. Seevastu vene keeles ei ole kestusel fonoloogilist rolli;

- rõhku väljendatakse eesti ja vene keeles erinevate akustiliste parameetrite abil - eesti keeles on rõhu peamisteks korrelaatideks põhitooni sagedus ja intensiivsus, vene keeles on selleks eelkõige kestus;

- häälikute kvaliteedihälbed on tingitud eesti ja vene keele häälikusüsteemide erinevustest (erinev vokaalide ja konsonantide hulk, häälikute artikulatoorsed erinevused).

Siinses artiklis esitatud tulemused on vaid sissejuhatuseks vene aktsendi olemuse uurimisse ja ei hõlma kaugeltki kõiki aktsendiga seotud aspekte. Saadud tulemuste põhjal kavandatakse erinevate aktsendinähtuste põhjalikum uuring.

\section{Tänuavaldus}

Tänan salvestustel osalenud keelejuhte, samuti retsensente artikli kohta esitatud kasulike märkuste eest.

\section{Kirjandus}

Best, Catherine T. 1995. A Direct Realist View of Cross-Language Speech Perception. Speech Perception and Linguistic Experience. Issues in Cross-Language Research. Ed. by W. Strange. York Press, Timonium, 171-203.

Bondarko = Бондарко, Л. В. 1977. Звуковой строй современного русского языка. Москва.

Brown, Douglas H. 1980. The Optimal Distance Model of Second Language Acquisition. TESOL Quarterly 14 (2), 157-164. 
Eek, Arvo; Meister, Einar 1997. Simple perception Experiments on Estonian Word Prosody. Foot Structure vs. Segmental Quantity. - Estonian Prosody: Papers from a Symposium. Ed. by I. Lehiste, J. Ross. Tallinn, 71-99.

Eek, Arvo; Meister, Einar 2003a. Domain of the Estonian Quantity Degrees: Evidence from Words Containing Diphthongs. - Proceedings of the 15th ICPhS, Barcelona, 2039-2042.

Eek, Arvo; Meister, Einar 2003b. Foneetilisi katseid ja arutlusi kvantiteedi alalt (I). Häälikukestusi muutvad kontekstid ja välde. - Keel ja Kirjandus 11, 815-837; 12, 904-918.

Eek, Arvo; Meister, Einar 2004. Foneetilisi katseid ja arutlusi kvantiteedi alalt (II). Takt, silp ja välde. - Keel ja Kirjandus 4, 251-271; 5, 336-357.

Flege, James E. 1995. Second Language Speech Learning. Theory, Findings, and Problems. - Speech Perception and Linguistic Experience. Issues in Cross-Language Research. Ed. by W. Strange. York Press, Timonium, 233-275.

Jilka, Matthias 2000. The Contribution of Intonation to the Perception of Foreign Accent. Doctoral Dissertation. - AIMS Working Papers 6 (3). Institut für Maschinelle Sprachverarbeitung, University of Stuttgart.

Kjellin, Olle 1999. Accent Addition. Prosody and Perception Facilitates Second Language Learning. - Proceedings of LP'98 (Linguistics and Phonetics Conference) at Ohio State University, Columbus, Ohio, September 1998. Vol. 2. Ed. by O. Fujimura, B. D. Joseph, B. Palek. Prague: The Karolinum Press, 373-398.

Kraut, Einar 2000. Eesti keele hääldamine. Tallinn: TEA Kirjastus.

Krull, Diana 1991. Stability in some Estonian duration relations. PERILUS 13. Institute of Linguistics, University of Stockholm, 57-60.

Krull, Diana 1992. Temporal and tonal correlates to quantity in Estonian. PERILUS 15. Institute of Linguistics, University of Stockholm, 17-36.

Kuhl, Patricia K. 1991. Human adults and human infants show a "perceptual magnet effect" for the prototypes of speech categories, monkeys do not. - Perception \& Psychophysics, 50, 93-107.

Kuhl, Patricia K.; Iverson, Paul 1995. Linguistic experience and the "perceptual magnet effect." - Speech Perception and Linguistic Experience. Issues in Cross-Language Research. Ed. by W. Strange. Publishers, Mahwah, New Jersey, London.

Meister, Lya 2005. Vene aktsent eesti keeles. Akustiline analüüs. Magistritöö. Tallinna Pedagoogikaülikool.

Piir, Hille 1985. Acoustics of the Estonian Diphthongs. - Estonian Papers in Phonetics 1982-1983, Tallinn, 5-103.

Praat. Versioon 4.2.15. Internetis: http://www.praat.org (15.1.2006).

Pols, Louis C. W. 1977. Spectral analysis and identification of Dutch vowels. Doctoral dissertation, University of Amsterdam, the Netherlands.

Rannut, Mart 2000. Vene aktsendist eesti keeles. - Eesti keele kui teise keele õpetamine I. Toim Ülle Türk. Haridusministeerium. Tallinn, 7-17.

Rannut, Mart 2003. Foneetilisest aktsendist eesti keeles. - Metoodilisi võtteid eesti keele õpetamiseks. Toim Tiina Rüütmaa. Tallinn, 28-36. Internetis: http://www.tpu.ee/ fil/veebitoimetised (15.1.2006).

Selinker, Larry 1972. Interlanguage. - International Review of Applied Linguistics 10, 209-231.

Trubetzkoy, Nikolai Sergeevich 1939. Grundzüge der Phonologie. Edition from 1958 by Vandenhoeck and Ruprecht, Göttingen.

Yamada, Reiko A. 1995. Age and Acquisition of Second Language Speech Sounds Perception of American English / I/ and / / by Native Speakers of Japanese. - Speech Perception and Linguistic Experience. Issues in Cross-Language Research. Ed. by W. Strange. York Press, Timonium, 305-320. 


\section{RUSSIAN ACCENT IN ESTONIAN: SOME RESULTS OF ACOUSTIC ANALYSIS}

\section{Lya Meister}

The present study investigates Russian accent in Estonian. It is assumed that when native speakers can perceptually recognize non-native accent, it also should manifest itself in several acoustic features. The primary goal of the study is to find quantitative characteristics of different phenomena of Russian accent in Estonian.

The basic premises of the study are the following:

- most of foreign accent phenomena detected by perceptual analysis can be measured using different methods of acoustic analysis;

- comparative analysis of acoustical data from both native and non-native speech in the context of phonological systems of speaker's native and target languages forms the basis for explanation of various accent phenomena.

For the acoustic analysis a speech corpus including isolated words and short sentences representing different vowels, diphthongs, consonants, consonant clusters, syllable structures and quantity degrees has been recorded by two groups of speakers. L2-group involved 14 Russian speakers, mostly students of Estonian as L2 (12 female, 2 male) and in L1-group two native speakers of Estonian (1 female, 1 male) were involved.

The acoustic features measured in the study were:

- duration of different segments - stressed and unstressed vowels, diphthongs, consonants;

- duration ratios of stressed and unstressed syllables;

- formant frequencies of stressed and unstressed vowels;

- formant trajectories of diphthongs;

- correlates of word stress - Fo peaks and intensities of stressed and unstressed syllables;

- duration and voicing of stop consonants.

The values of acoustic features measured from accented speech were compared to those of native speech.

The main results of the study are:

- Russian accent in Estonian exhibits itself in a combination of different acoustic features the most relevant of which are the deviations in (1) temporal structure, (2) stress correlates, and (3) quality of sounds;

- the roots of foreign accent lay in the differences of phonological systems of Estonian and Russian;

- most of the accent phenomena investigated in the study can be explained by the transfer of L1 patterns to production of Estonian.

Keywords: non-native accent, phonetics, vowels, duration of sounds and syllables, duration ratio, stress, acoustic analysis, Estonian, Russian 
Lya Meister (1957) on lõpetanud Tallinna Pedagoogilise Instituudi vene keele ja kirjanduse eriala. 2005. a kaitses eesti filoloogia magistrikraadi Tallinna Pedagoogikaülikoolis, misjärel astus Tartu Ülikooli doktoriõppesse eesti ja soome-ugri keeleteaduse erialale. Töötab TTÜ Küberneetika Instituudi foneetika ja kõnetehnoloogia laboratooriumis teaduri ametikohal. Peamised uurimisvaldkonnad on eksperimentaalfoneetika, kõne andmebaasid, võõrkeelse aktsendi olemus. lya@phon.ioc.ee 